Judith M. Lieu

\title{
Marcion and the Corruption of Paul's Gospel
}

\begin{abstract}
That Marcion's authoritative texts were a form of the canonical Gospel of Luke and a Pauline corpus is well established, yet the relationship between these is far less certain. Although it is widely assumed that Marcion identified or authorised his gospel through a reading of Paul's defence of his gospel in Gal 1-2, this relies heavily on Tertullian who is driven by his own rhetoric and agenda. Tracing the different defences by Irenaeus and Tertullian of the authority of the gospel and of conflict between Paul and Peter alerts us to the complex negotiations involved in the textualization of the early Christian message, and in the attempts to hold together the Pauline revolution and the remembering of Jesus traditions. Marcion represents a different stage in this process, and although we can reconstruct for him a narrative, it is one which is fragmentary and remains allusive. Contemporary attempts to get beyond the rhetoric and special pleading must always be sensitive to the ideological framing that has accompanied narratives of the past from the start.
\end{abstract}

Keywords: Marcion, gospel, Paul, Irenaeus, Tertullian

Judith M. Lieu: University of Cambridge, Faculty of Divinity, West Road, Cambridge CB3 9BS, United Kingdom, e-mail: jml68@cam.ac.uk

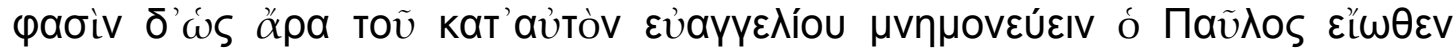

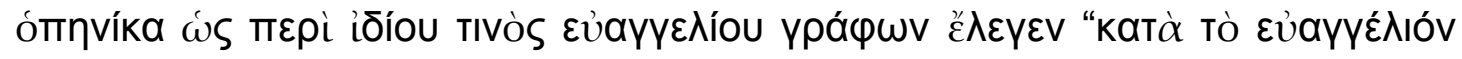
nou."1

One of the many features of Marcion which make him such an intriguing and potentially pivotal figure for any understanding of the second century is the consistency of the charge that he did not produce any new scriptures or writings attributed to Christ or to the first apostles, but that he took his starting point from the church's own scriptures, selecting from them Luke and the Pauline corpus, and subjecting even these to tendentious revisionary excision. ${ }^{2}$ Particularly over the last century, interest has focused on how his gospel-production and/or his reading of Paul fit within the literary trajectory to the New Testament. Yet how these two came together remains something of a mystery; classically, and under the influence of Tertullian and of Adolf von Harnack, the connection has been found in Paul's defence of "his gospel" in

\footnotetext{
${ }^{1}$ Eusebius, Historia Ecclesiastica 3,4,7 (GCS 9,1, 194,2-4 Schwartz/Mommsen).

${ }^{2}$ See Judith M. Lieu, Marcion and the Making of a Heretic: God and Scripture in the Second Century (Cambridge, 2015), esp. 183-187, 234. Some of Marcion's opponents make no reference to his scriptural practices or do so only generally; how far Marcionism continued without distinctive scriptures is a matter of debate.
} 
Gal $1-2 .^{3}$ It will be argued here that while this answer is too simple the question helps shed light on the complex processes of textualization in the second century.

\section{Irenaeus}

In addition to this, he mutilates the Gospel according to Luke, doing away with everything that is written about the birth of the Lord, and removing much about the teaching of the words of the Lord in which the Lord is described as openly acknowledging the builder of this universe as his own father; so he persuaded his disciples that he himself was more to be trusted than those apostles who handed down the gospel, handing down himself not the gospel but a piece of gospel. Similarly he cut away at the letters of Paul the apostle, removing whatever was explicitly said by the Apostle about that God who made the world, that he is Father of our Lord Jesus Christ, and whatever the Apostle taught making use of the prophetic announcements of the coming of the Lord. ${ }^{4}$

The earliest references to Marcion are silent about any scriptural texts; in Justin Martyr's case this is hardly surprising given his own limited awareness of, or interest in, any particular stable written form of the gospel tradition, or of a Pauline collection at all, ${ }^{5}$ but the tradition on which Irenaeus draws also seems to have lacked any reference. ${ }^{6}$ The report, cited above, that Irenaeus adds to that is therefore, even if reliable, already couched in terms that reflect his own context and interests.

So, he regularly charges any who challenge the tradition of the church with claiming to be superior to the apostles, ${ }^{7}$ more particularly, the counter-charge that Marcion has but "a piece of the gospel" is an Irenaean coinage driven by his own emphasis on the "the gospel" as the single proclamation that is shared by all the apostles, that is preserved through the tradition of the

\footnotetext{
${ }^{3}$ See below, and especially Adolf von Harnack, Marcion: Das Evangelium vom fremden Gott, eine Monographie zur Geschichte der Grundlegung der katholischen Kirche (2d rev. and enl. ed.; TU 45; Leipzig, 1924), 30-40.

${ }^{4}$ Irenaeus, Adversus haereses 1,27,2 (SC 264,2, 350,19-32 Doutreleau/Rousseau): Et super haec, id quod est secundum Lucam Euangelium circumcidens et omnia quae sunt de generatione Domini conscripta auferens et de doctrina sermonum Domini multa auferens, in quibus manifestissime Conditorem huius uniuersitatis suum Patrem confitens Dominus conscriptus est, semetipsum ueraciorem esse quam sunt hi qui Euangelium tradiderunt apostoli suasit discipulis suis, non Euangelium, sed particulam Euangelii tradens eis. Similiter autem et apostoli Pauli epistolas abscidit, auferens quaecumque manifeste dicta sunt ab Apostolo de eo Deo qui mundum fecit, quoniam hic Pater Domini nostri Iesu Christi, et quaecumque ex propheticis memorans Apostolus docuit praenuntiantibus aduentum Domini.

${ }^{5}$ For Justin Marcion is one who teaches another God, blaspheming the creator: see 1 Apologia 26,5; 58,1 (PTS 38, 70,20-25; 114,1-8 Marcovich); Dialogus cum Tryphone 35,6 (PTS 47, 129,28 Marcovich). On Justin's gospel text see Arthur J. Bellinzoni, The Sayings of Jesus in the Writings of Justin Martyr (Novum Testamentum, Supplements 17; Leiden, 1967).

${ }^{6}$ This is indicated by the change in construction at Irenaeus, Adversus haereses 1,27,2 (SC 264,2, 350,9-33 R./D.).

${ }^{7}$ Irenaeus, Adversus haereses 3,2,2; 3,12,12 (SC 211, 26,20-21; 232,417-418 Rousseau/Doutreleau).
} 
church, and which of necessity has four faces or personifications. ${ }^{8}$ This emphasis necessarily entails for Irenaeus a degree of ambiguity or fluidity between the written gospels as fixed texts and the gospel as proclaimed, as becomes evident as he struggles to articulate what it was that was both novel and threatening about Marcion's activity. ${ }^{9} \mathrm{He}$ had already established the insidious threat posed by the interpretive moves of the Valentinians, "adapting" (adaptare) the good things said in scripture to their evil intentions, and "attempting to establish proofs from the evangelic and apostolic (writings), overturning interpretations, and corrupting exegeses." 10 Marcion, by contrast, "is the only one who has openly dared to mutilate the scriptures," and yet he is nonetheless subsumed alongside "all who in some way or other adulterate the truth and harm the proclamation of the Church" and "are the disciples and successors of Simon Magus." ${ }^{11}$ Here the undoubtedly textual is firmly located within the framework of the "rule of truth" (regula veritatis), which provides the measure by which the scriptures are to be read, and of the church's preaching. ${ }^{12}$ Hence the language of mutilation and removal extends beyond editorial activity to serve Irenaeus' own emphasis on the inextricable interdependence of the unity of the church's tradition, of its scriptures, and of the church itself as the only locus of salvation. ${ }^{13}$

Marcion's treatment of the Pauline letters is simply subsumed into Irenaeus' primary defence of "the gospel"; even when he states that Marcion and his followers not only cut away at the Gospel of Luke and epistles of Paul but also assert that those, as diminished by them, are alone "legitimate" (legitima), he offers no additional model of what the completeness of the epistles might mean. ${ }^{14}$ Despite their importance for his own reading of Paul, he is either unconcerned at, or more probably unaware of, the absence of the Pastoral Letters from Marcion's collection, which a generation later Tertullian takes as evidence of a determination to mutilate Paul's letters "even in number." 15 More important for him is the need to establish not only against Marcion but also against Simon and Valentinus the antiquity and unity of the apostolic witness to the harmony of the one God and his economy of salvation.

\footnotetext{
${ }^{8}$ Irenaeus, Adversus haereses 3,11,9 (SC 211, 170,237-176,282 R./D.).

${ }^{9}$ See Annette Yoshiko Reed, "ЕҮАГГЕ $\mathrm{ION}$ : Orality, Textuality, and the Christian Truth in Irenaeus' Adversus Haereses," VigChr 56 (2002): 11-46, who labels these "the Pauline and Marcionite meanings" (ibid., 27).

${ }^{10}$ Irenaeus, Adversus haereses 1,3,6 (SC 264,2, 60,91-93 D./R.): ex euangelicis et apostolicis temptant ostensiones facere, conuertentes interpretationes et adulterantes $(=\quad \delta 100 \rho \gamma \varepsilon ́ \omega)$ expositiones.

${ }^{11}$ Irenaeus, Adversus haereses 1,27,4 (SC 264,2, 352,53-62 D./R.): solus manifeste ausus est circumcidere Scripturas . . omnes qui quoquo modo adulterant ueritatem et praeconium Ecclesiae . . . Simonis Samaritani magi discipuli et successores sunt.

12 Irenaeus, Adversus haereses 4,35,4 (SC 100,2, 874,113-876,119 Rousseau/Hemmerdinger/Doutreleau/Mercier).

${ }^{13}$ Irenaeus, Adversus haereses 3,14,4; 4,33,7-8 (SC 211, 274,126-140 R./D.; SC 100, 816,118820,148 R./H./D./M.)

${ }^{14}$ Irenaeus, Adversus haereses 3,12,12 (SC 211, 232,418-422 R./D.).

${ }^{15}$ Tertullian, Adversus Marcionem 5,1,9 (SC 483, 80,7-9 Moreschini/Braun): etiam de numero; cf. 5,21,1 (SC 483, 372,2-6 M./B.).
} 
For Irenaeus the most telling evidence of this unity was the meeting of "the universal church" (uniuersa ecclesia) in Acts 15, where he mentions Paul and Barnabas' participation only in passing. Here Peter's behaviour described in Gal 2:12-13 provides supporting evidence of the deliberate harmony between the apostles (Peter and James) and of their common affirmation of the one God, who was responsible also for the law of Moses, while Paul is only mentioned as reporting that Barnabas joined with them. ${ }^{16}$ There is little indication that Irenaeus was aware of any alternative reading of the incident, particularly one adopted by Marcion.

Even when he turns to those who think that only Paul knew the truth, he fails to identify these. Within a catena of scriptural examples of the parity between the Twelve and Paul, he appeals again to the incident in Acts 15, but now combines it with Gal 2 so as to make Paul himself testify to the other apostles. First, he modifies his earlier paraphrase of Acts 15:2 to incorporate a covert allusion to the account in Galatians he will quote later: Quoniam autem his qui ad apostolos uocauerunt eum de quaestione acquieuit Paulus et ascendit ad eos cum Barnaba in Hierosolymam. ${ }^{17}$ He continues with a direct appeal to "what Paul himself said in the letter to the Galatians" (ipse ait in ea quae est ad Galatas epistola) citing Gal 2:1-2 immediately followed by 2:5; the effect of omitting any reference to the question of Titus' circumcision and to the interference of false brothers (2:3-4), and of reading verse 5 without the initial relative pronoun and negative of the major Greek witnesses, is that Paul's momentary or opportune "submission" was to those who had summoned him. ${ }^{18}$ The evidentiary circle is completed as Irenaeus claims that any careful reader of Acts can confirm that the time span Paul names (Gal 2:1) agrees with the account of Paul's journey to Jerusalem propter praedictam quaestionem. ${ }^{19}$ In so doing he anticipates, and probably initiates, a long interpretive strategy in regard to both passages, ${ }^{20}$ but again there is no hint that others appealed to Gal 2 in support of the position he opposes.

As Irenaeus develops his argument it becomes clear that there are two mutually reinforcing strands; Acts proves itself to be by one who was "inseparable from Paul and his collaborator in the gospel"21; at the same time, Paul, by testifying to Luke as one who "always preached with Paul (2 Tim

\footnotetext{
${ }^{16}$ Irenaeus, Adversus haereses 3,12,14-15 (SC 211, 238,470-250,561 R./D.).

${ }^{17}$ Irenaeus, Adversus haereses 3,13,3 (SC 211, 256,41-43; cf. 41-56 R./D.). Cf. Acts 15:2: $\tau \alpha \xi \alpha v$

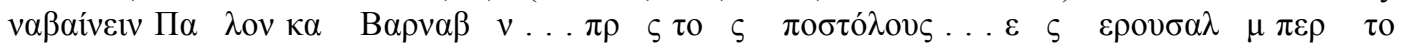

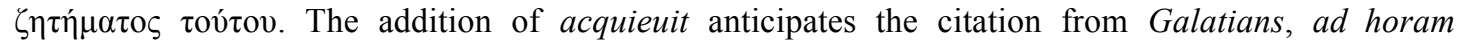
cessimus subiectioni, although the verb acquieui is read by many Latin witnesses at Gal 1:16.

${ }^{18}$ Irenaeus, Adversus haereses 3,13,3 (SC 211, 256,44-45 R./D.). The omission of o $\varsigma$ o $\delta \varepsilon ́$ implied by his reading of verse 5 (note 17) is attested by $\mathrm{D}^{*}$ and other western witnesses, cf. the critical apparatus of Nestle-Aland ${ }^{28}$ (Barbara and Kurt Aland et al., eds., Novum Testamentum Graece [28th rev. ed.; Stuttgart, 2014], 580).

${ }^{19}$ Irenaeus, Adversus haereses 3,13,3 (SC 211, 256,52-53 R./D.), cf. at note 17 above.

${ }^{20}$ See René Kieffer, Foi et justification à Antioche: interpretation d'un conflit (Ga 2,14-21) (Lectio Divina 111; Paris, 1982).

${ }^{21}$ Irenaeus, Adversus haereses 3,14,1 (SC 211, 258,1-2 R./D.): inseparabilis fuit a Paulo et cooperarius in Euangelio; cf. 2 Cor 8:18.22.
} 
4:10-11), who was described by him as beloved (Col 4:14), who evangelized with him, and is accepted as reproducing for us (a/the) gospel," becomes the guarantor both of the authority of Acts, and of its author, identified as Luke. ${ }^{22}$ This symbiosis excludes any possibility that Paul taught further mysteries unknown to Luke, and at the same time provides a defence against those who reject Luke as not knowing the truth. Luke self-evidently produced (a/the) gospel of the one whom he followed as a disciple (cf. Luke 1:2): here Irenaeus provides the support for the claim he had assumed earlier, that Luke's Gospel is the record ("in a book" [in libro]) of the gospel Paul preached. ${ }^{23}$ Now he parades all the details "that are necessary to the gospel" (necessaria Euangelii) that are found through Luke alone, which, he claims, both Marcion and Valentinus use; although he returns to the charge that Marcion accepts some, rejects others, while Valentinus subjects them to devious interpretations, he gives no indication of any awareness of the contents of Marcion's version of Luke. ${ }^{24}$

As is widely recognized, Irenaeus played a significant role in establishing the authority of Acts and positioning it as the lens through which Paul, and his relations with the other apostles, would be understood. The analysis above also demonstrates the significance of Luke in this argument, as the bookish form of Paul's gospel. Yet nowhere does he appeal to Paul's own language of "gospel" either in support of his own claims or in challenge to alternative conclusions concerning the relation of that gospel to "Luke" or concerning the events behind Gal 2. Further, when he turns in Book Five to what he sees as the real issue, namely the interpretation-or misinterpretation-by the heretics of Paul's language in his letters, not least regarding the unity of God and the reality of the bodily resurrection, no part is played by any substantial debates over the nature and contents of the Pauline corpus, by charges about the wilful editing of the text, or, in particular, by Luke's Gospel.

\section{Tertullian}

In general terms Tertullian follows and develops the outline initiated by Irenaeus: he takes for granted that the gospel Marcion claims as his own and as the true gospel bears such a close relationship to the church's Luke that it can be none other than a bowdlerized version of it; similarly Marcion's version of Paul's letters can be nothing more than a distortion of those read in the church, now with the specific omission of the Pastoral Letters. Like Irenaeus, he assumes that Marcion's basic policy was to remove anything that contradicted his own opinions, although that his failure to do so consistently

\footnotetext{
${ }^{22}$ Irenaeus, Adversus haereses 3,14,1 (SC 211, 262,42-48 R./D): semper cum Paulo praedicauit et dilectus ab eo dictus est et cum eo euangelizauit et creditus est referre nobis Euangelium. See Rolf Noorman, Irenäus als Paulusinterpret: Zur Rezeption und Wirkung der paulinischen und deuteropaulinischen Briefe im Werk des Irenäus von Lyon (WUNT II 66; Tübingen, 1994), 42-52.

${ }^{23}$ Irenaeus, Adversus haereses 3,1,1 (SC 211, 24,23-24 R./D.).

${ }^{24}$ Irenaeus, Adversus haereses 3,14,3-4 (SC 211, 266,24-274,140 R./D.).
} 
made it possible to refute those very opinions on the grounds of what he preserved. $^{25}$

In detail, however, the shape of his account, and its development over time, suggest considerable independence. When he made his first forays against Marcion in the Prescription of Heretics, his knowledge of him was largely formulaic, and it seems unlikely that he had any detailed awareness of the nature of Marcion's own scriptures. His celebrated comment that Marcion used the "sword and not the pen in order to slaughter the scriptures for his own purpose" explicitly contrasts Valentinus' expository expansions; the absence of reference to any written gospel, including Luke, suggests his primary target is Marcion's "separation of the New Testament from the Old."26 He had, however, encountered unnamed opponents who suggested that Paul's rebuke of Peter and those with him (Gal 2:14) implied that his own gospel marked an advance on theirs: Paul had introduced "another form of the gospel" (aliam evangelii formam; cf. Gal 1:6). His response was that Paul's visit to get to know Peter signaled acknowledgement of the latter's authority, and that their agreement was based on a division of spheres not of the gospel-effectively eliding the visits of Gal 1:18-24 and 2:7-9; any fault by Peter was one of "behaviour not of proclamation" (conversationis fuit vitium, non praedicationis). ${ }^{27}$ His primary concern was to defend the harmony and the consistency of the churches founded by the apostles and the tradition they handed on, and so he finds it necessary to reject the claims by the heretics that the Pauline churches had already been taken hostage, asserting that the apostle had successfully brought them back (Gal 1:6;3:1; 5:7). ${ }^{28}$ Evangelium here clearly indicates that which is proclaimed.

Tertullian apparently knew little more about Marcion's writings when he began his more targeted refutation in the Against Marcion, in what was originally intended as a single volume, and was only in stages expanded to a threevolume work (ca. 207/208 C. E.): in Book 1, perhaps in later editorial additions, he made only a general allusion to Marcion's "corrosion of the gospels," and to his plans to refute Marcion from his own scriptures. ${ }^{29}$ Marcion's followers claimed, he said, only that "Marcion did not bring in a new rule by the separation of law and gospel so much as restore one that had been subsequently falsified," ${ }^{30}$ appealing for support to Paul's rebuke of "Peter and the rest" (Petrum ceterosque) for not "correctly walking by the truth

\footnotetext{
${ }^{25}$ Tertullian, Adversus Marcionem 4,6,2 (SC 456, 88,9-90,14 Moreschini/Braun).

26 Tertullian, De praescriptione haereticorum 30,9 (CChr.SL 1, 211,28-30 Refoulé): novum testamentum a vetere separavit; 38,8-9 (219,21-25 R.): machaera, non stilo usus est, quoniam ad materiam suam caedem scripturarum confecit.

${ }^{27}$ Tertullian, De praescriptione haereticorum 23 (204,1-205,32 R.).

${ }^{28}$ Tertullian, De praescriptione haereticorum 27 (208,1-209,17 R.).

${ }^{29}$ Tertullian, Adversus Marcionem 1,1,5 (SC 365, 104,40 Braun): euangelia conrosit; 1,29,9 (SC 365, 246,71-73 B.).

${ }^{30}$ Tertullian, Adversus Marcionem 1,20,1 (SC 365, 190,3-5 B.): Marcionem non tam innouasse regulam separatione legis et euangelii quam retro adulteratam recurasse.
} 
of the gospel" (Gal 2:14). Tertullian retorted that although "false brothers" (falsi fratres) did aim to transfer the Galatians to another gospel (Gal 1:6), Paul himself demonstrated that any adulterium euangelii was not directed towards a transfer of faith in another God or Christ but to the maintenance of "the discipline of the law" (disciplina legis). Any offence was a matter of behaviour, not of preaching - and, after all, Paul himself was equally capable of the same practice "as a Jew to the Jews" (Iudaeis quasi ludaeus et eis; 1 Cor 9:20). ${ }^{31} \mathrm{He}$ then went on the offensive, arguing that there was no evidence in Paul's letters of any controversy in his own time about the identity of God, and that "even if the truth suffered adulteration (adulterium) concerning the rule (regula) of God after apostolic times," that was in no way the case during them, and so the testimony of the faith of "apostolic churches" stands to secure the original preaching of the gospel. ${ }^{32}$ The primary force of euangelium continues to be that which is preached. Although as he extended the enterprise to Book 3 he increasingly recognized the need to address Marcion's written gospel, his actual knowledge of it remained imprecise. ${ }^{33}$ Hence it seems likely that he only began to acquire a close knowledge of Marcion's Gospel when he turned to write Book 4 after an interval occupied with other work. Unsurprisingly, the argument now becomes explicitly textual. On the one hand, this was determined by his realization that everything turned on its unmistakable relationship with the church's Gospel of Luke. To some extent he could address this within his own principles. He had to secure for the corpus of written gospels (evangelicum instrumentum) the qualities of priority-in his framework the mark of authenticity-and of apostolicity; their authors were the apostles on whom Christ imposed the preaching of the gospel, reinforced by their disciples, "apostolic men" (apostolicis). On this basis Marcion's Gospel was doubly disqualified, first by its lack of a title and hence of any such claim, but also as an obviously mutilated form of that by Luke, who not only belonged to the secondary apostolic group, but was dependent on a later apostle, Paul, who himself acknowledged his need to gain approval from the apostles in Jerusalem that his preaching of the gospel did not differ from theirs (cf. Gal 2:2.9). ${ }^{34}$

Yet, as he understood it, Marcion had a twofold counter-challenge: Marcion had "lighted upon" (nactus) Galatians, and, by combining Paul's rebuke of "those apostles" (ipsi apostoli, Gal 2:14) with the perversion of the gospel by "false apostles" (pseudoapostoli, Gal 1:7; 2:4-5), had sought to undermine, in

\footnotetext{
${ }^{31}$ Tertullian, Adversus Marcionem 1,20,1-4 (SC 365, 190,1-192,28 B.).

${ }^{32}$ Tertullian, Adversus Marcionem 1,21,4 (SC 365, 198,24-25; cf. 24-31 B.): Quodsi post apostolorum tempora adulterium ueritas passa est circa Dei regulam. Praedicatio is repeatedly used in these chapters.

${ }^{33}$ See Tertullian, Adversus Marcionem 3,11,3-4; 3,15,7; 19,4; 3,24,8 (SC 399, 112,15-21; 142,51-52; 166,20-24; 208,61-63 Braun). Oblique references (e. g. 2,15,3; 2,17,1 [SC 368, 98,20-25; 106,67108,10 Braun]; 3,13,6 [SC 399, 124,34-126,39 B.]) refer to Matthean material. The Antioch incident is not mentioned in Books 2 or 3.

${ }^{34}$ Tertullian, Adversus Marcionem 4,2,1-3 (SC 456, 66,1-68,24 M./B.).
} 
Tertullian's own terminology, "the gospels which were rightly published under the names of the apostles and apostolic men, presumably in order to confer on his own the confidence he takes from them." ${ }^{35}$ As Tertullian understood it, this was an appeal to Paul in order to attack the gospel as preached, and as then transmitted to writing, by the apostles, although he leaves open whether the apostles themselves were at fault or those who immediately handed on the truth they preached. If taken seriously it could undermine Tertullian's own account by locating the loss of authenticity at the very beginning of the process. In what follows he counter-attacks through a characteristic gambit of imaginary scenarios founded on the authenticity of that which came first, and the necessarily derivative character of any supposed correction, buttressed by an appeal to the authentic tradition of the churches, in order to demonstrate the primacy of his Luke in harmony with the other gospels. ${ }^{36}$ However, as he repeatedly sets off against each other Luke against "the apostles," "the apostles" against Marcion, and Marcion against Luke, as authorities behind the true gospel, a skirmish enacted by the problem of the title which Marcion's Gospel lacked, it is evident that his own reading of Gal 2:2.9 is always in mind.

In principle his defence of Peter and John and James (sic) remains the same as in his previous discussions: it was for their manner of life, not preaching, and this remains true even of the false apostles, who were insisting on circumcision and Jewish calendrical observation. Yet his reading of that and of the whole debate is unmistakably textual: implicit, if not stated, is that the gospel the apostles compared with Paul's was effectively documentary (illud apostolorum instrumentum), of which the written gospels were derivative, as commentarii or digesta. ${ }^{37}$ Where, he asked, is the authentic gospel (of the apostles) that subsequently suffered at the hands of "the adulterers" (adulteri)? Is any dispute over the authorship a matter of "the title itself being adulterated" (adulterato etiam circa titulum)? Why did Marcion not correct the other gospels if they too were adulterated? ${ }^{38}$ In so doing he draws attention to the fluidity in the reference of "gospel" as it connects but also separates "preaching" (praedicatio) and "document" (instrumentum), and to the way that he has manipulated that fluidity in his argument.

It would be tempting to suspect that in Book 4 he was simply re-playing his earlier discussions of Gal 2 now directed to Marcion's written gospel. However, the distinctive character of his defence in Book 4, compared with his treatment of the same chapters of Galatians in Book 5, does suggest that he

\footnotetext{
${ }^{35}$ Tertullian, Adversus Marcionem 4,3,2 (SC 456, 72,6-12 M./B.): ad destruendum statum eorum euangeliorum quae propria et sub apostolorum nomine eduntur, vel etiam apostolicorum, ut scilicet fidem, quam illis adimit, suo conferat.

${ }^{36}$ Marcion's Gospel, Tertullian admits, also has its churches, but these are necessarily more recent in time, and hence "apostatic rather than apostolic" (facilius apostaticum inuenias quam apostolicum) (Adversus Marcionem 4,5,3 [SC 456, 84,17-20 M./B.]).

${ }_{37}$ Tertullian, Adversus Marcionem 4,2,4; 4,3,4 (SC 456, 70,25-28; 74,30-31 M./B.).

${ }^{38}$ Tertullian, Adversus Marcionem 4,3,4-5; 4,5,5 (SC 456, 74,27-76,41; 86,36-40 M./B.).
} 
was responding to a Marcionite apologetic, although the widespread assumption that he found this in Marcion's Antitheses, which he had now encountered for the first time, though attractive, is far from secure. He refers explicitly to them only in Book 4, where he described them as a "sort of dowry" (dotem quandam), perhaps an explanatory reading-guide, for the gospel; ${ }^{39}$ yet, his failure to address them, despite promises to do so, and the absence of any reference to them in Book 5 , do provoke some to doubt as to whether he had ever studied them closely. ${ }^{40}$

Nonetheless, it is this that established the framework within which he then turned to "exposition of the adulterated gospel, except not Jewishpresumably as claimed by Marcion-but Pontic." ${ }^{41}$ As he works through Marcion's Gospel, albeit with increasing speed, he adopts the language of textual revision, identifying removal of material and emendation (aufero, interpolo, erado, emendo)-although in practice specific comments on their distinctive elements are still comparatively sparse, and his base text is as often Matthew as canonical Luke; any attempt at reconstruction must bear in mind that he is driven as much as elsewhere by the demands of polemical rhetoric. $^{42}$ Instead he directs more energy and eloquence to establishing from his opponent's own texts the prime principles of the unity of God, creator and father, of the fleshly reality of Jesus, and of the resurrection of the flesh in order to receive the just judgement for deeds done in the flesh.

This set the pattern for Book 5 analysing the Apostolikon, which followed later, and thus fundamentally transformed both the character and the length of the whole work. Nonetheless, the wider theme of a deliberate falsification of the text by Paul's opponents is much less dominant there: It is Tertullian who ironically suggests that "perhaps our false apostles and Jewish evangelists" introduced part of Col 1:16b absent from Marcion's text. ${ }^{43}$ References to Marcion's Gospel are few and far less polemical, and Tertullian even appeals to "our shared instrumentum" (commune instrumentum; Luke 4:34). ${ }^{44}$

\footnotetext{
${ }^{39}$ Tertullian, Adversus Marcionem 4,1,1 (SC 456, 56,4-5 M./B.).

40 So Gerhard May, Gesammelte Aufsätze (ed. Katharina Greschat and Martin Meiser; Veröffentlichungen des Instituts für Europäische Geschichte Mainz: Beihefte Abendländische Religionsgeschichte 68; Mainz, 2005), 47. See also Lieu, Marcion (see note 2), 272-288. At Adversus Marcionem 4,2,1 (see note 41), prior to explaining Marcion's appeal to Galatians, he had claimed to move on from the Antitheses to proving the corruption of his gospel. His assertion that Marcion demonstrated per antithesis/es suas that the gospel had been falsified may refer as much to rhetorical style as to a specific work (Tertullian, Adversus Marcionem 4,4,4 [SC 456, 78,30-80,33 M./B.]; see note 78 ).

${ }^{41}$ Tertullian, Adversus Marcionem 4,2,1 (SC 456, 66,2-4 M./B.): Transeo nunc ad euangelii, sane non Iudaici sed Pontici, interim adulterati, demonstrationem.

${ }^{42}$ See Dieter T. Roth, The Text of Marcion's Gospel (New Testament Tools, Studies and Documents 49; Leiden, 2015), 83-91.

${ }^{43}$ Tertullian, Adversus Marcionem 5,19,5 (SC 483, 350,39-40 M./B.): pseudoapostoli nostri et Iudaici euangelizatores de suo intulerint. See note 53 for Tertullian's association of pseudoapostoli with euangelizatores.

${ }^{44}$ Tertullian, Adversus Marcionem 5,6,7 (SC 483, 152,57 M./B.); cf. 5,3,6 (SC 483, 98,52 M./B.); see also 5,9,7 (SC 483, 200,54 M./B.) where he appeals to his long demonstration of the reliability of "the
} 
Returning to the interpretation of Gal 2, he identifies the issue provoked by the false brothers as a matter of "ancient discipline" (ueteris disciplinae), namely continued observance of the law, and in no way related to any manipulation of scripture. ${ }^{45}$ Although he does accuse Marcion of altering the text and of removing material from Paul's letters, it is the theology to which this leads, in particular the relationship between "law and gospel," that is his primary concern. Behind this lies the battle not just over what Paul said but over how the right understanding of Christ is to be authenticated. This is what, in commenting on Colossians, he calls "our rule" (regulam nostram) or "the evangelic (gospel) tradition" (traditio euangelica): even if Marcion does claim to possess this, his has no right to the label apostolic; even were it to demonstrate universal spread, it lacks the essential mark of priority. ${ }^{46}$

\section{Marcion}

Tertullian's shifting attempts to defend his own position may seem to offer the tantalizing hope of recovering Marcion's alternative strategies and goals; yet it has become obvious that any glimpses will always be distorted by their refraction through Tertullian's powerful rhetorical skill, and that to attribute directly to Marcion the intentions, words or even actions with which Tertullian credits him is mistaken. Nonetheless, Tertullian's own defence together with close analysis of his reading of Marcion's Apostolikon do permit some attempt at cautious reconstruction.

Certainly, there can be little doubt that Galatians played a formative role in Marcion's understanding, or justificatory narrative, of the earliest progress of the message of Christ, whether this was encouraged by, or itself provoked, the position of Galatians at the front of his Pauline corpus. ${ }^{47}$ As seen above, he was probably not the only person to find in the letter evidence of a decisive conflict between Paul and Peter, with their respective associates, where interpreters had to decide what balance to strike between Paul's rebuke of Peter and his consultative trip to Jerusalem, as evidence of status and of more long-term relationships. All such readings demanded some degree of selectivity and of elisions between different stages in the complex chronology implied by canonical Galatians. Within this general narrative of conflict Marcion apparently focused more intently on Paul's fear that the Galatians be

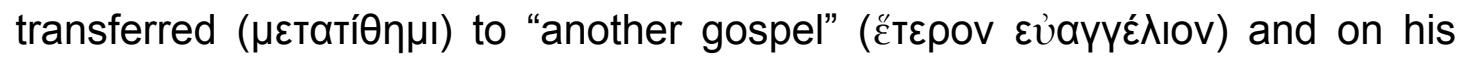
warning against those who "want to change ( $\mu \varepsilon т \alpha \sigma т \rho \varepsilon \varphi \omega)$ the gospel of Christ" (Gal 1:6-7). ${ }^{48}$ For these purposes ignoring or perhaps unaware of the

\footnotetext{
gospels we have published" (Nos edimus euangelia) with reference to the Magi's star and the shepherds' angelic annunciation.

${ }^{45}$ Tertullian, Adversus Marcionem 5,3,2 (SC 483, 92,13-15 M./B.).

${ }^{46}$ Tertullian, Adversus Marcionem 5,19,1-2; cf. 5,20,2 (SC 483, 346,1-348,15; SC 362,14-364,25 M./B.).

${ }^{47}$ Lieu, Marcion (see note 2), 234-240, and on what follows, 242-248.

${ }^{48}$ Enrico Norelli, "La Funzione di Paolo nel Pensiero di Marcione," Rivista Biblica 34 (1986): (543597) 556 for elision of 6 and 7. In the Dialogue of Adamantius (De recte in deum fide) 1,6 (PTS 55,
} 
intervening passage (Gal 1:10-24), he assumed the identity of those responsible for this "other" or "perverted" gospel with those ( $\psi \varepsilon \cup \delta \alpha \delta \varepsilon \dot{\lambda}(\varphi \mathrm{O})$ who attacked Paul's freedom in Gal 2:4. Like many others, Marcion identified or associated these with Peter, whom Paul charges with not observing the

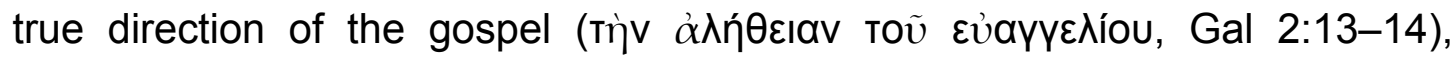
perhaps implicating the other apostles with him, represented by "the rest of

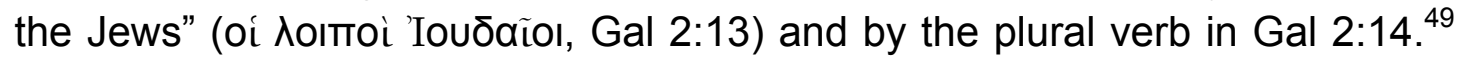
This provided the basic narrative of a deliberate distortion by false messengers associated or identified with Peter of the true gospel revealed to and preached by Paul, and of his unequivocal resistance: Paul did not submit, "in order that the truth of the gospel might remain" (iv $\alpha \dot{\eta} \dot{\alpha} \lambda \hat{n} \theta \varepsilon ı$ tov

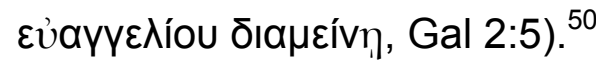

As Harnack and others have observed, for Marcion those who "perverted (perverto) the gospel of Christ" were not "false brothers" ( $\psi \varepsilon \cup \delta \alpha \delta \varepsilon \dot{\lambda}\left\langle\mathrm{ol}_{\text {, falsi }}\right.$

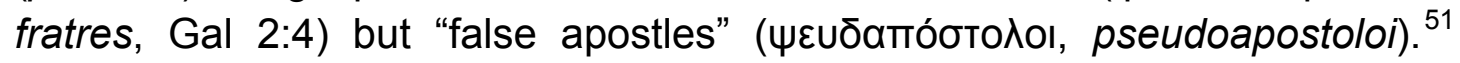
Since Tertullian does not question this, although elsewhere he assumes the correct reading, it may have had a wider currency than Marcion alone; he himself had glossed Gal 2:4 that Paul labelled those who wished to transfer the gospel from its newness to its oldness "false apostles and brothers" (falsos et apostolos et fratres). ${ }^{52}$ Behind it may lay an older tradition: his rhetorical question in the De praescriptione, "Who are false prophets except false preachers, who are false apostles except adulterous evangelists, who are antichrists, now and always, except rebels against Christ?" may be traced earlier, perhaps to a dominical agraphon. ${ }^{53}$ However, the association is most directly dependent on the reference to $\psi \varepsilon \cup \delta a \pi$ ó

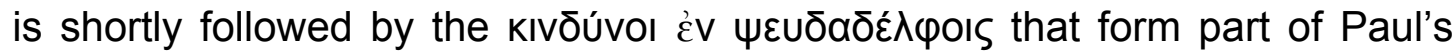
catalogue of the trials he had faced (2 Cor 11:26), a passage Tertullian

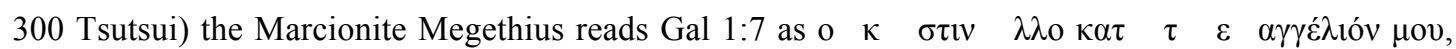
cf. Rom 2:16; despite other evidence that this Pauline formula was cited by Marcionites against four gospels (Origen, In Johannem 5,7 [SC 120, 386 Blanc]), this is probably later apologetic, and its addition here is not otherwise attested.

${ }^{49}$ Cf. Tertullian, De praesciptione haereticorum 23,5 (205,12-15 R.): Petrus et ceteri. Given the identification of Peter as "a Jew" in Gal 2:14, the suggestion by Norelli, "Funzione" (see note 48), 557 that Marcion omitted "Jews" in Gal 2:13 is unnecessary.

${ }^{50}$ Marcion did not read "to whom" (o s), thus generalizing Paul's resistance; for Tertullian his reading of o $\delta \varepsilon ́$ was a characteristic uitiatio scripturae: Tertullian, Adversus Marcionem 5,3,3 (SC 483, 94,20 M./B.); see also note 18.

${ }_{51}^{51}$ Tertullian, Adversus Marcionem 4,3,2 (SC 456, 72,8-9 M./B.); Harnack, Marcion (see note 3), 37.

${ }^{52}$ Tertullian, Adversus Marcionem 1,20,4.6; 5,3,3 (SC 365, 192,25 and 194,51-54 B.; SC 483, 94,16 M./B.); cf. Tertullian, De resurrectione mortuorum 24,13 (CChr.SL 2, 952,35-38 Borleffs). The equivalence also enters the Latin commentary tradition, possibly via the so-called Marcionite Prologues.

${ }^{53}$ Tertullian, De praescriptione haereticorum 4,4 (205,12-15 R.): Qui pseudoprophetae sunt nisi falsi praedicatores? Qui pseudoapostoli nisi adulteri evangelizatores? Qui antichristi, interim et semper,

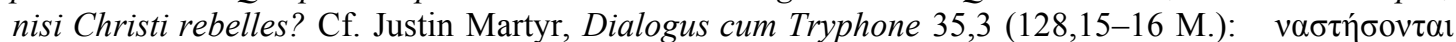

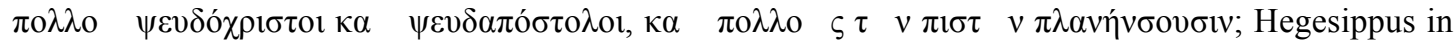

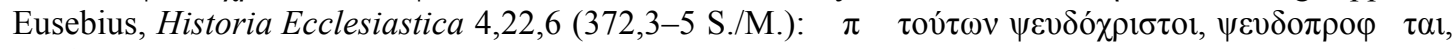

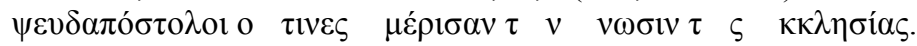


ignores.$^{54}$ More pertinently for the Marcionite framework, these false apostles, whose identity is not clarified, are further described as "workers of deceit" and as "transforming themselves into apostles of Christ" ${ }^{\text {" }}$ (2 Cor 11:13) adding support to an elision between Peter with his fellow apostles and those whom Paul accused of perverting the gospel. Tertullian himself ignores the phrase "into apostles of Christ," perhaps not from oversight but to avoid treading on Marcion's exegetical ground. As Paul continues, "And no wonder-for Satan himself transforms himself into an angel of light, so it is no great matter if his servants transform themselves as servants of righteousness," Tertullian objects that this cannot be a reference to the creator, who is a god and not an angel. ${ }^{56}$ Such an identification highlights further possible cross-references-to

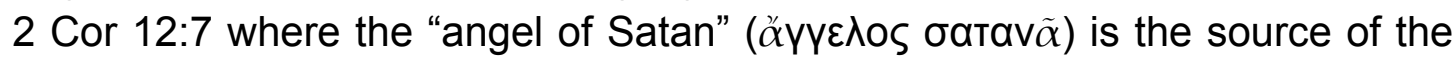
distress which even Paul experiences, despite or in attack against the visions he is given; and perhaps also to Paul's initial complaint: Tertullian claims that, for Marcion, Paul's invocation of an anathema "even if (we or) an angel from heaven were to evangelize other than what I evangelized" indicated that the Demiurge was the initiator of the perversion of the true gospel. ${ }^{57}$

Marcion clearly did find explicit evidence of the Creator's work earlier in 2 Corinthians, in 4:1-6, in a context allowing further cross-allusions to these references. This passage was of undoubted importance, in part for its

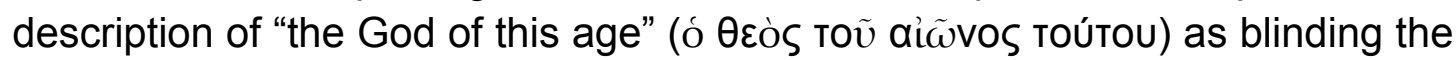
minds of unbelievers to prevent them beholding the "illumination of the gospel

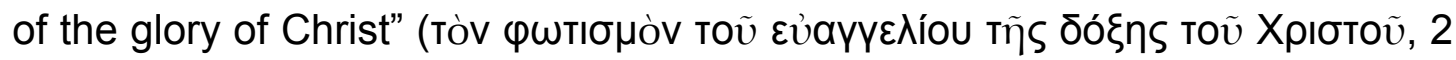
Cor 4:4). Without specific reference to Marcion, Irenaeus had already criticized this parsing together with the conclusion that it referred to another deity; the problem was not one of the text but of knowing how to read it and where to make breaks - "of this age," he claims, should be taken with "unbelievers" ( $\mathrm{T} \tilde{\omega} \mathrm{\alpha} \dot{\alpha} \pi i ́ \sigma \mathrm{T} \omega \mathrm{V}) .{ }^{58}$ While Tertullian was tempted by the same solution, grammatical honesty forced him to allow for other possibilities that

\footnotetext{
${ }^{54}$ The elision between "false brothers" and "false apostles" works better in Greek than in Latin (falsi/ ficti fratres-pseud(o)apostoli).

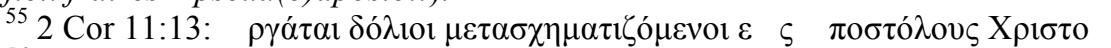

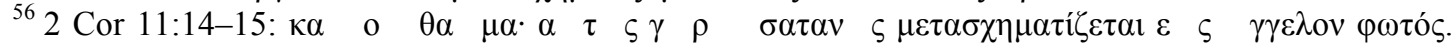

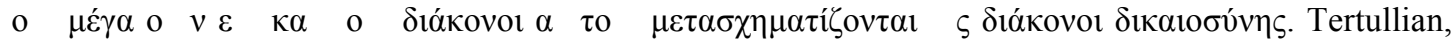
Adversus Marcionem 5,12,6-7 (SC 483, 252,53-60 M./B.)

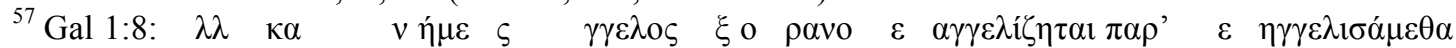
$\mu \mathrm{tv}$. Tertullian, Adversus Marcionem 5,2,5-6 (SC 483, 88,61-72 M./B.): Ceterum si nec ipse aliter euangelizaturus, utique nec angelus. Ita angelum ad hoc nominauit, quo multo magis hominibus non esset credendum, quando nec angelo et nec apostolo, non angelum ad euangelium referret Creatoris. It is not certain that Marcion omitted "we or" ( $\mu \varepsilon \delta)$ since quotations of the verse often do omit it for exegetical purposes; Marcion did more probably omit "to you" ( $\mu \nu)$ after "were to evangelize"

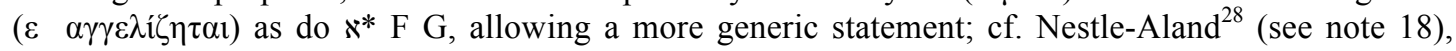
578, apparatus ad locum.

${ }^{58}$ Irenaeus, Adversus haereses 3,7,1-2 (SC 211, 80,11-88,55 R./D.).
} 
would take the word order more seriously. ${ }^{59}$ However, dealing with one verse alone did not dispense with the problem: Marcion found other references to "the God of this age," also known as "the Creator," elsewhere, both in the epistles and in the Gospel. ${ }^{60}$

At this point Paul has just cleared himself ("us") of malicious behaviour or

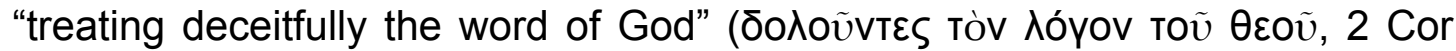
4:2); a close reader might infer that there were others who did so act, and this in turn would establish a further link with the false apostles in 2 Cor 11:13 as

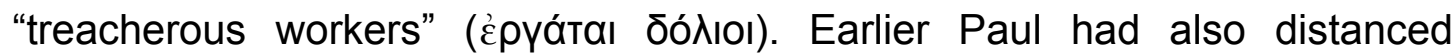
himself from "the many who peddle (or 'adulterate') the word of God" (oi

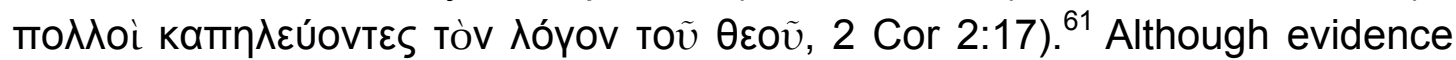
for Marcion's text is lacking, it is highly possible that, as often elsewhere, it

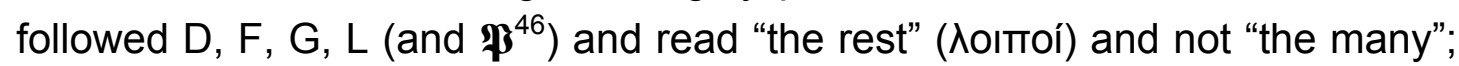
if so, a further connection would be possible with those ("the rest of the Jews") who joined Peter in his hypocrisy and failure and in being rebuked by Paul in Gal 2:13-14. ${ }^{62}$

It is tempting to follow these trails yet further, even if it becomes difficult to distinguish between lively imagination and sharp eyes. ${ }^{63}$ Towards the end of Galatians Paul continues his appeal, apparently demonstrating that the conflict was far from over-contrary to those who found in chapter 2 an affirmation of reconciled unity and co-operation. Obstruction of the truth, harassment, and deceit continue, with one apparent significant perpetrator behind them: "You were running well; who prevents you from obeying the truth? Such persuasion does not come from the one who called you. A little yeast defrauds the whole dough. . . . Whoever is upsetting you will bear the

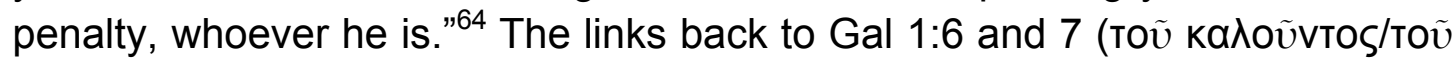

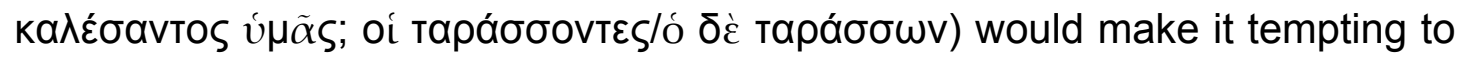
identify the unnamed disturber with Peter (as, according to Jerome, some did

\footnotetext{
${ }^{59}$ Tertullian, Adversus Marcionem 5,11,9-13 (SC 483, 234,79-240,128 M./B.): see Judith M. Lieu, "As Much My Apostle as Christ is Mine: The Dispute over Paul between Tertullian and Marcion," Early Christianity 1 (2010): 41-59.

${ }^{60}$ See Lieu, Marcion (see note 2), 224-227, 257-261.

${ }^{61}$ The meaning of $\kappa \alpha \pi \eta \lambda \varepsilon v ́ \omega$ is debated: Margaret E. Thrall, A Critical and Exegetical Commentary on the Second Epistle to the Corinthians 1: Introduction and Commentary on II Corinthians I-VII (Edinburgh, 1994), 212-215.

${ }^{62}$ On the text see Thrall, Second Epistle to the Corinthians (see note 61), 210-211 (note 148). For Gal 2:13-14, see at note 49 above.

${ }^{63}$ In addition to what follows there are hints of divergent readings of Paul's behaviour in 1 Cor 9; 1 Cor 9:5 sets up a further contrast between Paul and "the rest of the apostles . . . and Cephas"; Tertullian, for his part, appeals to 1 Cor 9:20.22 as evidence of Paul's more acquiescent behaviour (above, p. \#\#).

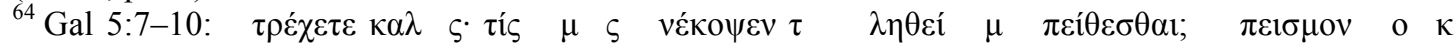

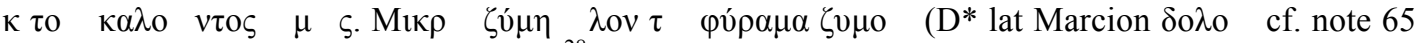

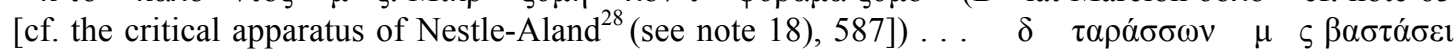

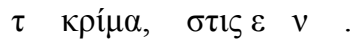




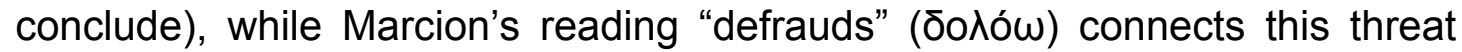
back to 2 Cor $4: 2$ and $2: 17 .{ }^{65}$

This narrative of conflict between Paul and the other apostles, identified by the vocabulary of Judaism, can be traced elsewhere through the letters as read by Marcion, and through the Gospel. ${ }^{66}$ In the present context two aspects are important. First, Marcion read the Pauline corpus, or parts of it, intertextually; he is the first witness to such an exercise in reading, and perhaps to a consciously collected corpus, although there may be earlier hints of both. ${ }^{67}$ Second, central to this reading alongside the theme of conflict is that of deceit and corruption.

It is at this point that the trail from Paul's gospel to Marcion's Gospel becomes most elusive. One path is tempting but proves misleading. Turning to Marcion's Gospel Tertullian declares, "I say mine is adulterated, Marcion mine" (ego Marcionis adfirmo adulteratum, Marcion meum) ${ }^{68}$ It is striking that

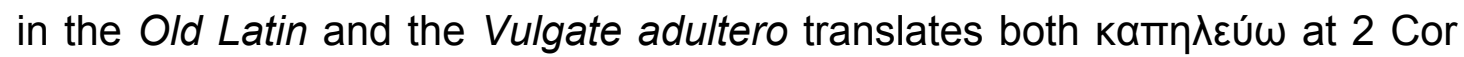

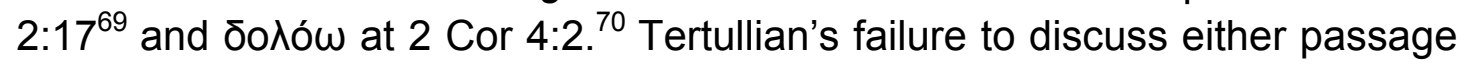
renders his reading unknown, but although his quotation of 2 Cor 11:13 uses dolosus for ठónıos, he himself protests-as he had in his defence of Peter and the false brothers-that the false apostles are accused "not of adulterated

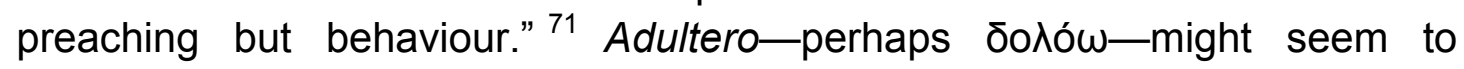
provide the link from Marcion's own charges against the false apostles to the written gospel.

Yet it is surely Tertullian who has created this, for both the dramatic declaration and the language serve his own antithetical rhetoric. The meaning of the root adult- had already been extended in Latin authors beyond the sexual to include other fraudulent activity or pretense at legitimacy, such as tampering with wine or oil. Tertullian insinuates that Marcion as a shipping manager no doubt adulterated the goods he carried for trade, presaging his

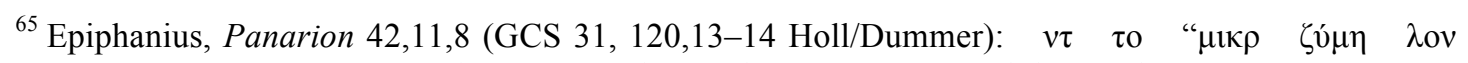

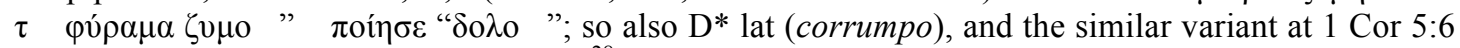
(cf. the critical apparatus of Nestle-Aland ${ }^{28}$ [see note 18], 501, 526). Tertullian gives no evidence at this point. Cf. Jerome, Ad Galatas 3,5,10b (CChr.SL 77A, 164,2-10 Raspanti).

${ }^{66}$ Harnack, Marcion (see note 3), 36-38.

${ }^{67}$ Lieu, Marcion, (see note 2), 238-242, and debates as to whether any of the Catholic letters presuppose a Pauline corpus.

${ }^{68}$ Tertullian, Adversus Marcionem 4,4,1 (SC 456, 76,2-3 M./B.); the neuter refers back to the previous section and to instrumentum.

${ }^{69}$ So already Irenaeus, Adversus haereses 4,26,4 lat. (SC 100,2, 726,104-108 R./H./D./M.).

${ }^{70}$ See note 61: contemporary interpretation continues to discuss whether the two terms are synonyms, and often appeals to Lucian, Hermotimus 59 (ed. Peter von Möllendorff, Lukian Hermotimos oder lohnt es sich, Philosophie zu studieren [Texte zur Forschung 74; Darmstadt, 2000], 100): Lycinus expounds his jaundiced view of philosophers as like peddlars (кá $\eta \eta \lambda \mathrm{ol})$ of wine, "most of them

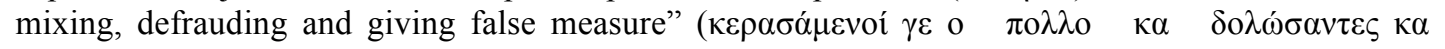

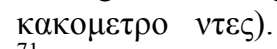

${ }_{71}$ Tertullian, Adversus Marcionem 5,12,6 (SC 483, 252,52-54 M./B.): conuersationis, non praedicationis adulteratae; contrast his earlier definition in De praescriptione haereticorum 4,4 of "false apostles" as "adulterous evangelists" (note 54).
} 
unreliability in the things of God. ${ }^{72}$ He had first applied the term to heresy in the Apology, ${ }^{73}$ and then developed this as a quasi-technical usage in the Prescription: while the apostles had needed to tackle adulterae doctrinae in their own time, Valentinus and Marcion together are now the more conspicuous and profligate adulteri veritatis; together they represent the heretical combination of the adulteria of scriptures with appeal to misleading interpretations. ${ }^{74}$ As a climax Tertullian accuses "heretical adultery" (or "adulterating") as responsible for having "debauched the pure virgin handed down by Christ," the Church, injecting the language of heresy with the conventional elision of sexual and religious infidelity, and of women's supposed susceptibility to irrational ideas. ${ }^{75}$ It is no surprise that, as has been seen, adultero is among his favoured terms to attack Marcion's activity. ${ }^{76}$

Here, as more generally, it would appear to be Tertullian who has injected textual overtones into the much more allusive language of anything that can be traced back to Marcion-who at most can be shown to have spoken of "adulterated preaching" or "rule."77 Even Tertullian never makes it explicit that "Paul's gospel" was, for Marcion, the written gospel known in the church as the Gospel of Luke: he relies on a suggested proximity between them, although one which to some extent remains elusive. His language continually infers ambiguity, both as to who was responsible for the adulteration of the gospel, and whether it was indeed his own Luke that Marcion argued was "touched up by the defenders of Judaism for the inclusion in a body of the law and prophets so as to fabricate a Christ from there"-a charge that would sound very different if referring to that which was preached. ${ }^{78}$ In fact the conclusion that Marcion deduced from Gal 1:6-7 the existence of, and then had to identify, the authentic written gospel is one that modern scholars have had to make, while the extension of the narrative to include the supposed adulteration of Paul's own letters is yet a further step and necessarily requires

\footnotetext{
${ }^{72}$ Tertullian, Adversus Marcionem 5,1,2 (SC 483, 72,20-21 M./B.), and cf. the quotation from Lucian at note 70 .

${ }^{73}$ Tertullian, Apologia 47,10 (CChr.SL 1, 164,40-44 Dekkers): praescribimus adulteris nostris.

${ }^{74}$ Tertullian, De praescriptione haereticorum 6,$2 ; 17-18 ; 30,12 ; 34,1 ; 38,1$ (191,5-6; 200,1-201,9; $211,34-35 ; 215,1-3 ; 218,1-2$ R.). The Latin translation of Irenaeus was probably influenced by this move: adultero represents varying Greek formulae: Irenaeus, Adversus haereses 1,3,6 (=

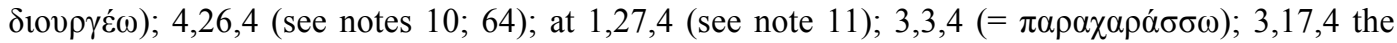
object of the verb is "truth" (cf. 3,15,1, "inadulteratam regulam") (SC 264,2, 42,92-93; 342,103-104; 278,25-26 R./D.).

${ }^{75}$ Tertullian, De praescriptione haereticorum 44,2 (223,5-6 R.): qui illam stupraverint adulterio haeretico virginem traditam a Christo. Cf. Hegesippus's account of the origins of heresy, prior to which the church had been called virgin, yet to be "corrupted by empty stories" ( $\varphi \theta \alpha \rho \tau$ о ко $\varsigma$ $\mu \alpha \tau \alpha i ́ a 15=$ Latin [Rufinus] adulterini verbi) (Eusebius, Historia ecclesiastica 4,22,4 [370,12-14; 371,13 S./M.]).

${ }^{76}$ See pp. \#\#, \#\#, and Tertullian, Adversus Marcionem 4,5,3; 4,17,13 (SC 456, 84,18; 224,89 M./B.).

${ }^{77}$ See p. \#\# and notes 30 and 71.

${ }^{78}$ Tertullian, Adversus Marcionem 4,4,4 (SC 456, 78,30-80,33 M./B.): interpolatum a protectoribus Iudaismi ad concorporationem legis et prophetarum, qua etiam Christum inde confingerent; for the disputed phrase, possibly Tertullian's own, ad concorporationem legis et prophetarum, see Lieu, Marcion (see note 2), 189 (note 13); 415-416. See note 40.
} 
The picture of Marcion as an editor of texts in the search for an authentic original may be a plausible one ${ }^{80}$ but it is one that largely has been orchestrated by his opponents. As they recognized, the battle over Marcion's message had more than individual significance, for it extended to the very nature of the divine economy, in particular as embodied in the interpretation of the (Jewish) scriptures through the lens of the church's own proclamation. Although that proclamation was not restricted to written format, the transmission and reading of texts was becoming an essential expression of it. Irenaeus and Tertullian witness to the vulnerabilities that accompanied that development-the vulnerabilities of textual change, those generated by the multiplicity of written gospels, ${ }^{81}$ and also the new conceptualization such a move entailed. Marcion becomes the means through which both Irenaeus and Tertullian can negotiate the tensions; in so doing they obscure the path that still inspires the contemporary question "How soon a book?"82 There is some irony in the fact that Marcion is now widely credited not only as responsible for the label, but also, more recently, as a prime instigator of the genre. ${ }^{83}$ Yet behind this instrumental Marcion, on whom so much is projected, lies a no less significant albeit shadowy figure.

Marcion and his various opponents represent significant, and significantly different, stages in the textualisation of ideas of truth and of gospel, as well as in attempts to hold together the Pauline revolution and the remembering of Jesus traditions. Each of these separate voices achieves its goal by a rewriting of the past. Those who seek to fashion new reconstructions do well to be sensitive to the ideological framing that all re-telling, and all recovery of past authority, entails.

\footnotetext{
${ }^{79}$ Harnack, Marcion (see note 3), 36-44, followed by a summary of his "changes"; Harnack concludes that Marcion began his revision with Paul's letters. Ironically in the light of recent proposals, Harnack commends Marcion for not succumbing to the temptation to compose "the authentic gospel" himself.

${ }^{80}$ As the present author has argued elsewhere: Lieu, Marcion (see note 2), 306-308, 416-417. The possibility of loss and distortion of a founder's original message was a philosophical commonplace, justifying numerous strategies of recovery and re-interpretation; but it could only be such because of the realities of textual corruption, falsification, and loss.

${ }^{81}$ Dionysius of Corinth complained about the "falsification" ( $\quad \delta 10 v \rho \gamma \varepsilon \dot{\varepsilon} \omega$, cf. note 74) of his own letters, and e minore found nothing unexpected in the similar falsification of the scriptures of the Lord: Eusebius, Historia ecclesiastica 4,23,12 (378,11-17 S./M.); cf. note 48.

${ }^{82}$ James A. Kelhoffer, "'How Soon a Book' Revisited: EYАГГЕ $\Lambda$ ION as a Reference to 'Gospel' Materials in the First Half of the Second Century," ZNW 95 (2004): 1-34.

${ }^{83}$ Matthias Klinghardt, Das älteste Evangelium und die Entstehung der kanonischen Evangelien (2 vols.; Texte und Arbeiten zum neutestamentlichen Zeitalter 60,1-2; Tübingen, 2015). It is not the intent of this paper to engage with such reconstructions but to urge a greater sensitivity to the ideological framing of all such narratives.
} 